\title{
Microstructure and Tensile Properties of Diffusion Bonded Austenitic Fe-Base Alloys-Before and After Exposure to High Temperature Supercritical- $\mathrm{CO}_{2}$
}

\author{
Sung Hwan Kim ${ }^{1}$, Ji-Hwan Cha ${ }^{1}$, Changheui Jang ${ }^{1, * \mathbb{D} \text { and Injin Sah }}{ }^{2}$ \\ 1 Department of Nuclear and Quantum Engineering, Korea Advanced Institute of Science and Technology, \\ Daejeon 34141, Korea; sciencetom@kaist.ac.kr (S.H.K.); jh_cha@kaist.ac.kr (J.-H.C.) \\ 2 Very High Temperature Reactor Technology Development Division, Korea Atomic Energy Research Institute, \\ Daejeon 34057, Korea; injin@kaeri.re.kr \\ * Correspondence: chjang@kaist.ac.kr; Tel.: +82-42-350-3824
}

Received: 15 March 2020; Accepted: 2 April 2020; Published: 4 April 2020

\begin{abstract}
Austenitic Fe-base alloys, SS 316H and Alloy 800HT, were diffusion bonded for use in compact-type heat exchangers in supercritical-carbon dioxide $\left(\mathrm{S}-\mathrm{CO}_{2}\right)$ Brayton cycles. For diffusion bonded $316 \mathrm{H}$, grain boundary migration across the bond-line was observed despite the formation of some $\mathrm{Cr}$-rich carbide, and its tensile properties were similar to those of as-received $316 \mathrm{H}$. However, diffusion bonded Alloy $800 \mathrm{HT}$ exhibited severely degraded elongation compared to as-received $800 \mathrm{HT}$ due to the formation of continuous Ti-rich carbides along the bond-line. Post-bond heat treatment (PBHT) was found to improve elongation at fracture for diffusion bonded alloys. However, a subsequent corrosion test in $\mathrm{S}-\mathrm{CO}_{2}$ at $600^{\circ} \mathrm{C}(20 \mathrm{MPa})$ for $1000 \mathrm{~h}$ resulted in a loss of elongation. This was much more severe for PBHT-ed $800 \mathrm{HT}$ due to the formation of Cr-rich carbides at the bond-line. Meanwhile, it was found that the effect of ageing on loss of elongation during high temperature exposure was greater than that of $\mathrm{S}-\mathrm{CO}_{2}$ environment.
\end{abstract}

Keywords: diffusion bonding; austenitic alloys; supercritical-carbon dioxide; ageing; carbides

\section{Introduction}

The supercritical-carbon dioxide $\left(\mathrm{S}-\mathrm{CO}_{2}\right)$ Brayton cycle is a cross-cutting power conversion technology which is notable for its high thermal efficiency, simple turbomachinery, and versatility [1]. Its possible applications range from next generation nuclear, fossil, and solar power plants, with each system characterized by specific operation conditions [2-6]. Therefore, the compatibility of structural materials in $\mathrm{S}-\mathrm{CO}_{2}$ environments at various temperatures and pressures, especially regarding corrosion behavior, was investigated. Generally, it was reported that Ni-base alloys exhibited superior corrosion resistance due to the formation of a thin and adherent Cr-rich oxide layer [7-10]. The corrosion behaviors of Fe-base alloys were found to be dependent on $\mathrm{Cr}$ content, grain size, and exposure temperature [11-14]. Meanwhile, compact plate type heat exchangers such as the printed circuit heat exchanger (PCHE) are likely to be adopted for $\mathrm{S}-\mathrm{CO}_{2}$ cycles $[15,16]$. The manufacture of a PCHE involves photo-chemical etching of candidate alloy plates to form passages through which coolant flows. Then, the etched plates are stacked on top of each other to form a block, which is then diffusion bonded to form a heat exchanger unit [17]. Thus, the performance of the joints of the diffusion bonded plates is of key importance to the integrity of the PCHE.

Diffusion welding or bonding is one of the joining methods grouped under solid-state welding processes. It is characterized by producing joints by maintaining contact of joining work pieces by applying pressure at high temperature under the melting point of the base materials in a controlled 
environment for a specified duration. If performed well, diffusion bonded joints show similar mechanical properties as the base material. In addition, diffusion bonding enables the joining of multiple plates for PCHE fabrication, which is difficult using other joining methods such as fusion welding or brazing. It is well known that the quality of a diffusion bond is sensitive to various bonding parameters such as temperature, pressure, and duration, as also indicated in the American Society of Mechanical Engineers (ASME) Boiler and Pressure Vessel Code, Section IX under Part QW. In addition, selecting optimum diffusion bonding conditions would differ for varying alloys, and would involve consideration of each alloys' mechanical properties, microstructures, and chemical composition [18,19]. For example, Gietzelt et al. conducted diffusion bonding on austenitic, ferritic, and martensitic stainless steels and reported that the highly alloyed steels required more severe conditions for a sound diffusion bond to be achieved [20]. In the case of Ni-base alloys, many studies have reported the poor joint efficiency of diffusion bonded Ni-base alloys in comparison to as-received alloys [17,20-23]. This was attributed to the formation of precipitates along the bond-line for those alloys, which induced brittle failure at that region during mechanical tests. Meanwhile, Sah et al. found that the tensile properties of diffusion bonded Alloys 230 and 617 could be recovered to a certain extent by the application of post-bond heat treatment (PBHT) [24].

In addition to the initial diffusion bond quality, the long-term integrity of these joints in a $\mathrm{S}-\mathrm{CO}_{2}$ environment would be crucial, as the PCHE would be exposed to high temperature $\mathrm{S}-\mathrm{CO}_{2}$ throughout its lifetime. Lee et al. exposed a diffusion bonded Alloy 600 to $\mathrm{S}-\mathrm{CO}_{2}$ at $650{ }^{\circ} \mathrm{C}(20 \mathrm{MPa})$ for $1000 \mathrm{~h}$ and found that the corrosion and carburization behavior at the joint did not differ from that of the base metal [25]. Dogan et al. also reported that the diffusion bond joints of Alloys 230 and 282 had little effect on their oxidation behavior in $\mathrm{CO}_{2}$ at $700{ }^{\circ} \mathrm{C}$ for $500 \mathrm{~h}$ [26]. Sridharan et al. performed hardness tests on diffusion bonded SS 310, SS 316, and Alloy 230 after exposure to a high temperature $\mathrm{S}-\mathrm{CO}_{2}$ environment and reported that in all cases, the bond-line did not seem to be a preferential site of carburization [27]. It should be noted that these studies focused on the corrosion behavior at the bond-line. However, detailed studies on the effects of long-term $\mathrm{S}-\mathrm{CO}_{2}$ exposure on the mechanical properties and microstructural changes of diffusion bonded alloys have rarely been conducted.

In the present work, austenitic Fe-base alloys, SS 316H and Alloy 800HT, were diffusion bonded at various temperatures; optimal conditions for their diffusion bonding were selected on the basis of their tensile properties. Then, the diffusion bonded specimens were subjected to corrosion tests in $\mathrm{S}-\mathrm{CO}_{2}$ at $600{ }^{\circ} \mathrm{C}(20 \mathrm{MPa})$ for $1000 \mathrm{~h}$. The microstructure and tensile property changes after $\mathrm{S}-\mathrm{CO}_{2}$ exposure were evaluated and discussed in view of the growth of carbides along the bond-line.

\section{Materials and Methods}

\subsection{Test Materials and Diffusion Bonding Process}

In this study, austenitic Fe-base alloys, SS 316H and Alloy 800HT, which are used in power generation systems, were selected. The alloys were provided in solution annealed states; their chemical compositions analyzed by inductively coupled plasma (ICP) spectroscopy are listed in Table 1 . For diffusion bonding, the alloys were machined into rectangular blocks $(20 \mathrm{~mm} \times 20 \mathrm{~mm}$ in length and width, and $10 \mathrm{~mm}$ in height). The bonding surfaces of each block were ground by SiC papers up to 4000 grit and then ultrasonically cleaned in ethanol. The blocks were then sent to be diffusion bonded by a local contractor (TNP Corporation, Korea). The bonding procedure was identical to that described in previous studies [24,25], and the bonding conditions for each alloy varied as specified by the authors, and as listed in Table 2. The bonding temperatures were set near the solution annealing temperatures for the alloys. When the target temperature was reached, the blocks were left for $10 \mathrm{~min}$ for temperature stabilization, and then a compressive force was applied to them for $1 \mathrm{~h}$. The pressure was set to avoid excessive plastic deformation of the bonding blocks at those temperatures. It was found that the heights of the diffusion bonded blocks before and after diffusion bonding were the same, which confirmed that noticeable deformation did not occur during diffusion bonding. 
Table 1. Chemical compositions of the alloys used in this study analyzed by ICP (in wt.\%).

\begin{tabular}{ccccccccccc}
\hline Alloy & Fe & Cr & Ni & Mo & Mn & Ti & Al & Si & Co & C \\
\hline SS 316H & Bal. & 17.3 & 10.7 & 2.2 & 0.64 & - & - & 0.6 & 0.16 & 0.05 \\
\hline Alloy 800HT & 42.3 & 21.0 & 33.9 & 0.2 & 0.93 & 0.55 & 0.48 & 0.4 & 0.05 & 0.06 \\
\hline
\end{tabular}

Table 2. Diffusion bonding conditions.

\begin{tabular}{|c|c|c|c|c|}
\hline Alloy & $\begin{array}{c}\text { Bonding } \\
\text { Temperature }\left({ }^{\circ} \mathrm{C}\right)\end{array}$ & $\begin{array}{c}\text { Compressive } \\
\text { Pressure (MPa) }\end{array}$ & Duration & Surface condition \\
\hline \multirow{2}{*}{ SS $316 \mathrm{H}$} & 1010 & \multirow{2}{*}{8} & & \multirow{5}{*}{$\mathrm{SiC} \mathrm{\# 4000}$} \\
\hline & 1050 & & Hold (10 mins) & \\
\hline \multirow{3}{*}{ Alloy $800 \mathrm{HT}$} & 1120 & \multirow{3}{*}{10} & + & \\
\hline & 1150 & & Pressure (60 mins) & \\
\hline & 1180 & & & \\
\hline
\end{tabular}

For tensile property evaluation, minisized tensile specimens $(16 \mathrm{~mm}$ in length and $0.5 \mathrm{~mm}$ in thickness, with a hole of $1.5 \mathrm{~mm}$ diameter on one of the heads) were fabricated by electro-discharge machining (EDM) from the diffusion bonded blocks, placing the bond-line at the center of the reduced section. The design of the tensile specimens was the same as that used in a previous work by Sah et al. [24]. Tensile tests were performed in a transverse direction perpendicular to the bond interface using a universal test machine (Instron Model 4204, Instron, Norwood, MA, USA ) at a strain rate of $3.33 \times 10^{-4} \mathrm{~s}^{-1}$. For the high temperature tensile test, the specimen was installed within the test zone, which was then heated and maintained at the target temperature by a furnace mounted on the testing machine. After the target temperature was reached, the temperature was held for $30 \mathrm{~min}$ before the tensile test was initiated.

\subsection{High Temperature $\mathrm{S}-\mathrm{CO}_{2}$ Test}

Based on the results of tensile tests, an optimum bonding condition for each alloy was selected. The tensile specimens were exposed to a S- $\mathrm{CO}_{2}$ environment at $600{ }^{\circ} \mathrm{C}(20 \mathrm{MPa})$ for $1000 \mathrm{~h}$. Schematics of the test equipment and procedure are described in detail in a previous study by the authors [8]. The minisized tensile specimens were installed on alumina boats by hanging by $\mathrm{Pt}$ wires. Alumina spacers were placed between the specimens to prevent direct contact with each other during the test. The alumina boat was placed in the $\mathrm{S}-\mathrm{CO}_{2}$ autoclave, which was then sealed. Then, research-grade $\mathrm{CO}_{2}(99.999 \%$ purity) was pumped in while the temperature of the autoclave was raised to the target temperature. When the test duration reached $1000 \mathrm{~h}$, specimens of each alloy were removed from the autoclave. At least two S- $\mathrm{CO}_{2}$-exposed specimens were subjected to tensile tests, while another specimen was taken without undergoing a tensile test for oxide analyses and microstructural characterization. Scanning electron microscopy (SEM, FEI Magellan 400, FEI Co., Hillsboro, OR, USA) equipped with energy dispersive X-ray spectroscopy (EDS) was utilized. For detailed analyses, transmission electron microscopy (TEM, Titan cubed G2 60-300, FEI Co., Hillsboro, OR, USA) equipped with EDS and electron energy loss spectroscopy (EELS) was used at an accelerating voltage of $300 \mathrm{kV}$ and a current of 70 pA. A focused ion beam (FIB, Helios Nanolab 450 F1, FEI Co., Hillsboro, OR, USA) was used to prepare the TEM specimens by the lift-out method.

\section{Results}

\subsection{Tensile Properties and Microstructures of the Diffusion Bonded Alloys}

Figure 1 shows the tensile properties of diffusion bonded SS $316 \mathrm{H}$ and Alloy $800 \mathrm{HT}$, as well as those of the as-received alloys. For SS 316H, the ultimate tensile strength (UTS) of the diffusion bonded 
specimens for both conditions was similar to that of the as-received condition at all test temperatures, i.e., from room temperature to $650^{\circ} \mathrm{C}$. In case of elongation, the $\mathrm{SS} 316 \mathrm{H}$ specimen bonded at $1010{ }^{\circ} \mathrm{C}$ showed slightly lower elongation compared to that bonded at $1050{ }^{\circ} \mathrm{C}$. For Alloy $800 \mathrm{HT}$, all bonded specimens showed lower UTS and elongation compared to the as-received one. It was shown that higher bonding temperatures resulted in better diffusion bonded joints, as atomic diffusion across the bond interface would be faster. Though there was an increase in UTS and elongation with higher bonding temperatures, the diffusion bonded Alloy $800 \mathrm{HT}$ specimens failed in a brittle manner at the center, where the bond-line was located.
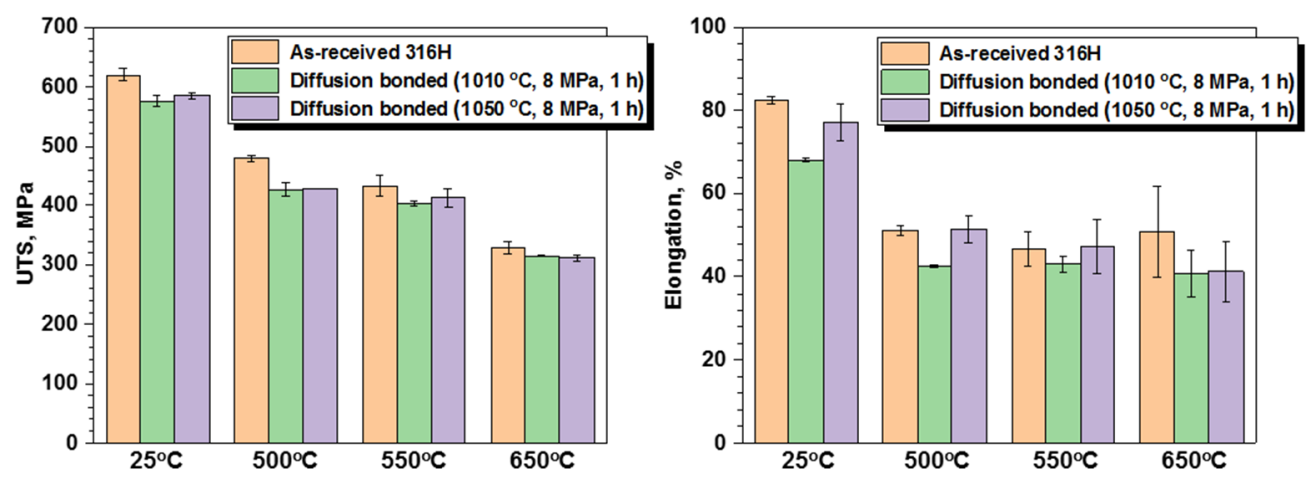

(a)
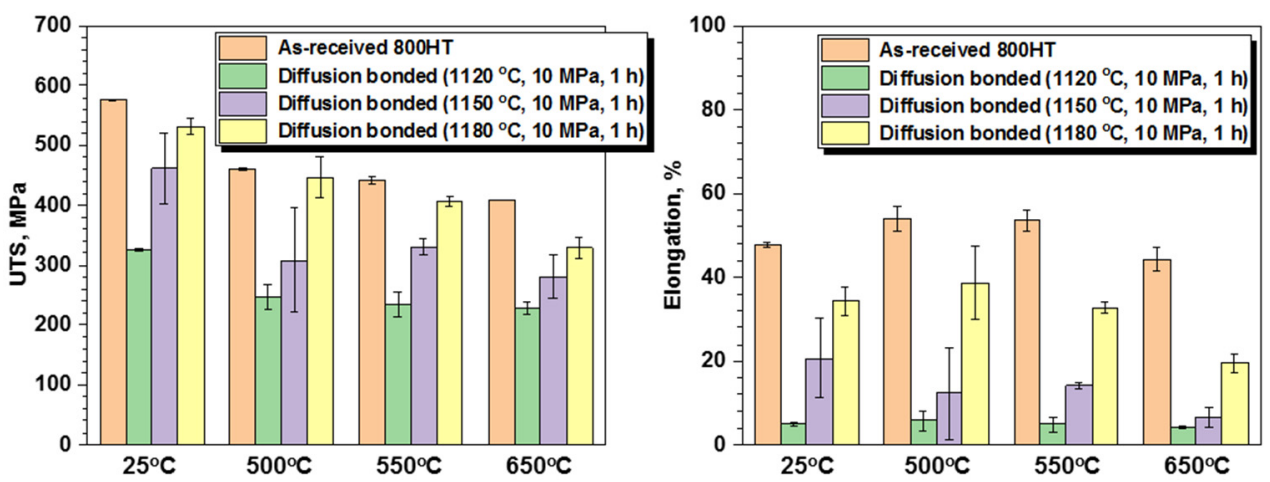

(b)

Figure 1. Tensile test results of diffusion bonded (a) SS 316 H and (b) Alloy 800HT compared to as-received materials.

SEM micrographs of diffusion bonded region of SS $316 \mathrm{H}$ bonded at $1050{ }^{\circ} \mathrm{C}(\mathrm{DB} 316 \mathrm{H})$ and Alloy $800 \mathrm{HT}$ bonded at $1150{ }^{\circ} \mathrm{C}$ (DB 800HT) are shown in Figure 2. Grain boundary migration across the bond-line was observed for SS 316H (Figure 2a), which was confirmed by electron backscatter diffraction (EBSD) analysis (Figure 2b). Nonetheless, the bond-line of diffusion bonded SS $316 \mathrm{H}$ could be identified due to the existence of small precipitates along the bond-line. In the case of Alloy 800HT, a planar bond-line was clearly identified in the SEM micrograph (Figure 2c). This indicates that grain boundary migration did not occur across the bond-line, which was confirmed by EBSD analysis (Figure 2d). In addition to the planar bond-line, small recrystallized grains were observed adjacent to the bond-line. It is thought that the compressive force applied during the diffusion bonding process resulted in local plastic deformation, which caused the dynamic recrystallization in the region adjacent to the bond-line. 


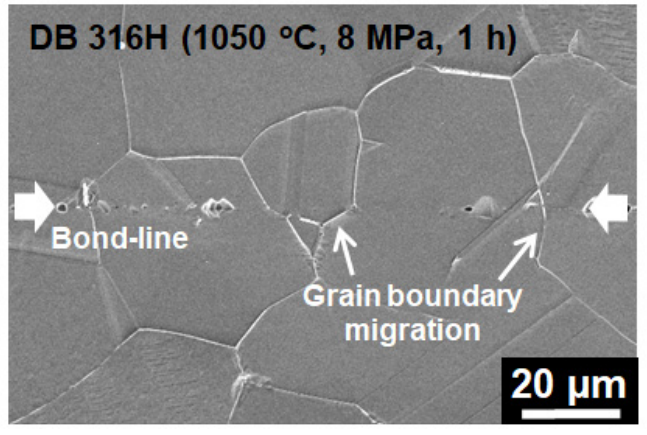

(a)

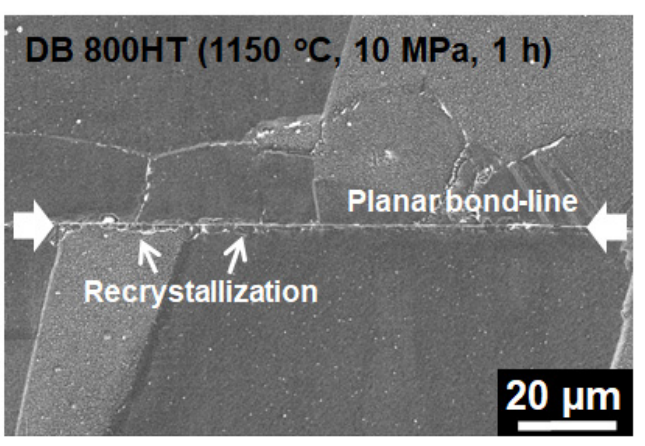

(c)

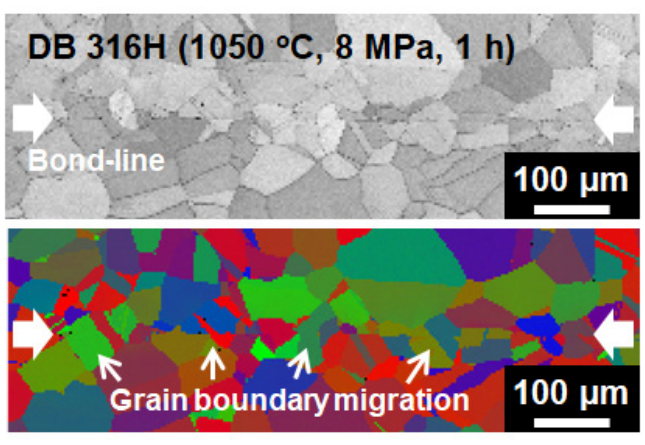

(b)
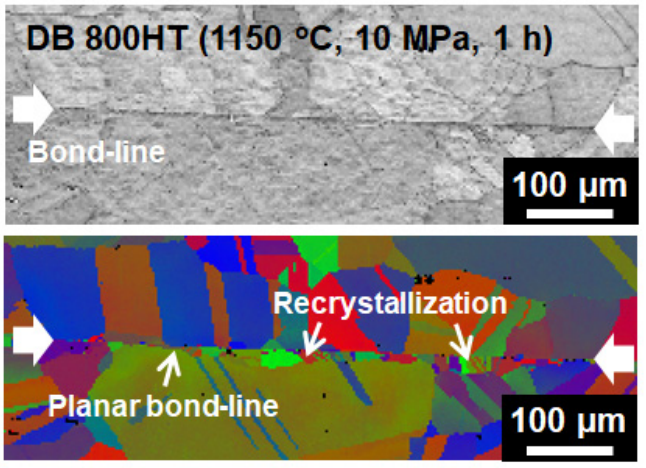

(d)

Figure 2. SEM micrographs of diffusion bonded (a) SS 316H and (c) Alloy 800HT, and EBSD results of diffusion bonded (b) SS $316 \mathrm{H}$ and (d) Alloy $800 \mathrm{HT}$ at the bond-line region.

TEM analyses were conducted on specimens extracted from the bond-line of diffusion bonded 800HT; the results are shown in Figure 3. Precipitates were formed continuously along the bond-line of diffusion bonded 800HT (Figure 3a). The EDS line scanning results indicate that the precipitate was rich mainly in Ti and C (Figure 3b), and was thought to be TiC.

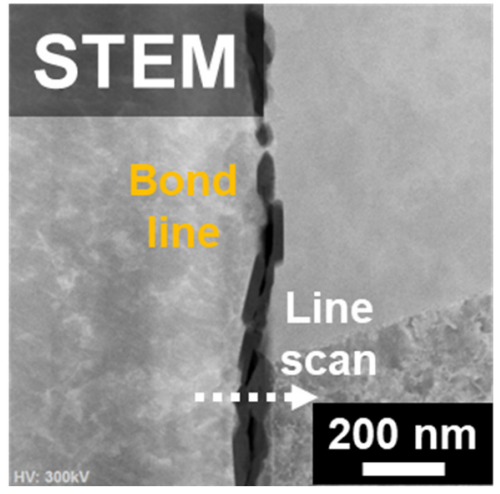

(a)

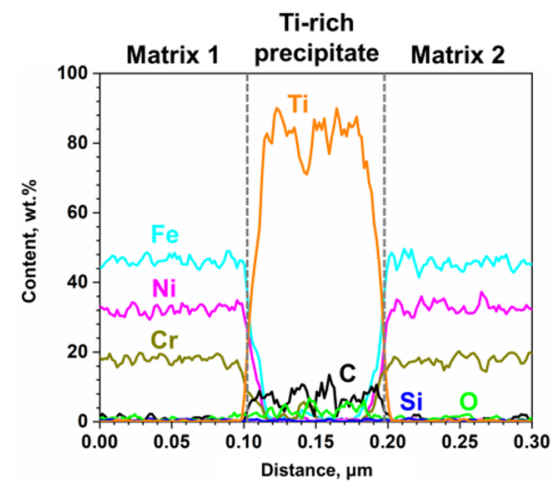

(b)

Figure 3. TEM analyses results of diffusion bonded Alloy 800HT at the bond-line; (a) STEM micrograph and (b) EDS line scan results.

\subsection{Effect of Post-bond Heat-Treatments}

Post-bond heat treatments (PBHT) were applied to the diffusion bonded specimens to remove the bond-line precipitates and improve tensile properties. PBHT was conducted in a vacuum $(<3 \times$ $10^{-6}$ torr) including heat-up $\left(5^{\circ} \mathrm{C} / \mathrm{min}\right)$ and cooling processes in order to avoid unintended oxidation 
prior to the corrosion test in $\mathrm{S}-\mathrm{CO}_{2}$. PBHT was conducted at $1100{ }^{\circ} \mathrm{C}$ for $5 \mathrm{~h}$ for diffusion bonded SS 316H; the results of tensile tests are shown in Figure 4a. It is shown that UTS slightly decreased, while elongation increased to higher values than the as-received condition, which could be due to grain growth during PBHT. Meanwhile, the bond-line was not identified in the microstructure of diffusion bonded SS $316 \mathrm{H}$ after PBHT (not shown). This indicates that the $\mathrm{M}_{23} \mathrm{C}_{6}$ carbides at the bond-line were dissolved into the matrix during PBHT, leaving only the migrated grain boundaries so that the original bond-line region could not be distinguished from the matrix. It should be noted that carbides may have re-formed along grain boundaries during cooling in vacuum. However, as the grain boundaries migrated across the bond interface, such re-formation of grain boundary carbides did not cause degradation of the tensile properties for PBHT-ed 316H (Figure 4a).
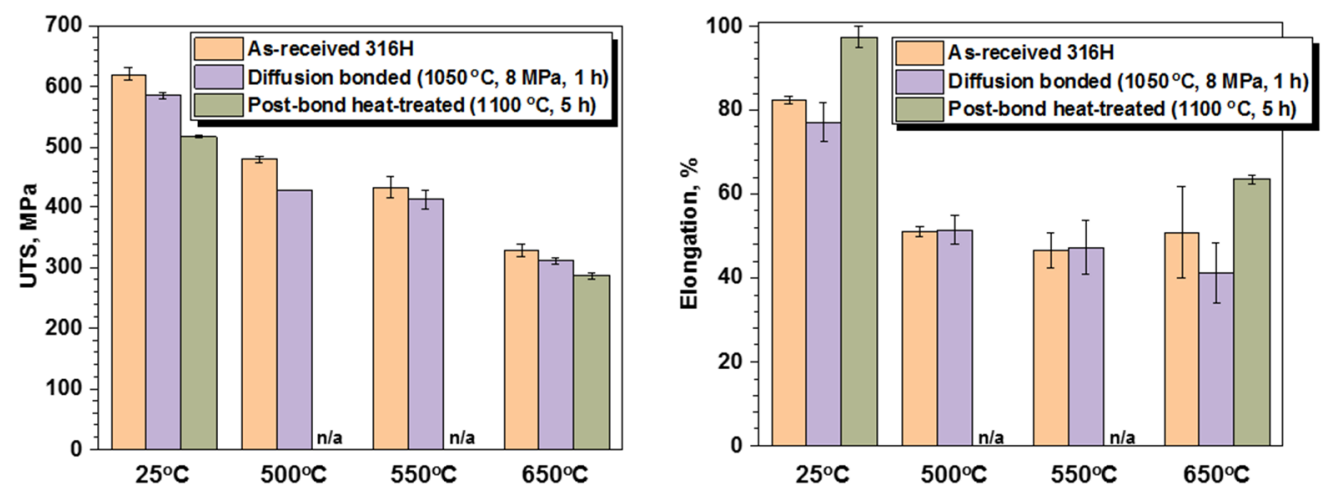

(a)
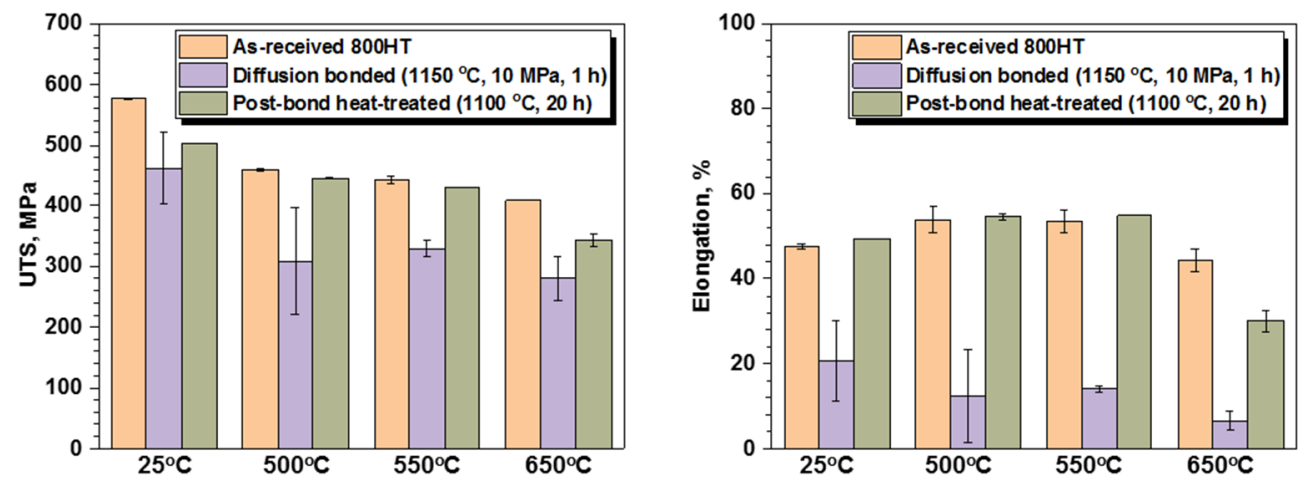

(b)

Figure 4. Tensile test results of PBHT-ed (a) SS 316H and (b) Alloy 800HT compared to as-received and diffusion bonded conditions.

For diffusion bonded Alloy $800 \mathrm{HT}$, PBHT was applied at $1100{ }^{\circ} \mathrm{C}$ for $20 \mathrm{~h}$. As shown in Figure $4 \mathrm{~b}$, PBHT resulted in recovered tensile properties to the level of the as-received condition up to $550{ }^{\circ} \mathrm{C}$. On the other hand, at $650{ }^{\circ} \mathrm{C}$, PBHT-ed specimen did not show complete recovery of elongation, and the tensile specimen failed at the center in a brittle manner. An SEM micrograph at the bond-line of the diffusion bonded $800 \mathrm{HT}$ after PBHT is shown in Figure 5a. The grain boundary migration across the bond-line did not occur, and the planar bond-line with precipitates remained even after PBHT. Meanwhile, the recrystallized grains that existed adjacent to the bond-line (Figure 2c,d) were not observed, which was probably the result of grain growth during PBHT. The results of the TEM/EDS analyses of the precipitates by TEM are shown in Figure 5b,c. The precipitates are composed mainly of Ti and C, suggesting that these are the same kind as those found after diffusion bonding of Alloy 800HT (Figure 3). However, the TiC precipitates increased in size after PBHT, and became twice the size of those in the as-bonded condition. In addition, while the carbides in the as-bonded condition were 
elongated and continuous along the bond-line, they became globular in morphology and discontinuous after PBHT.

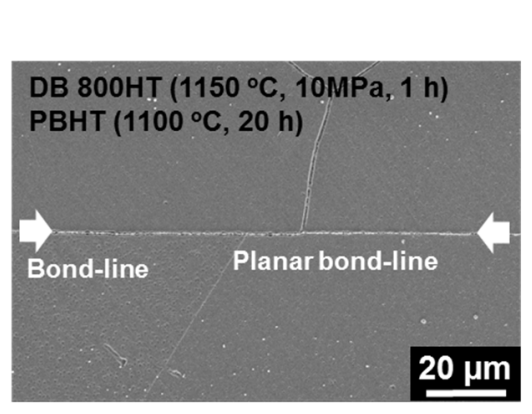

(a)

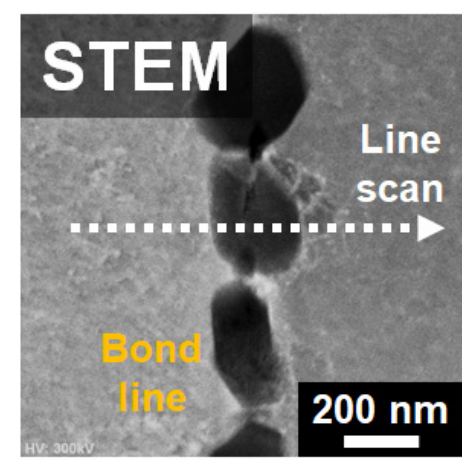

(b)

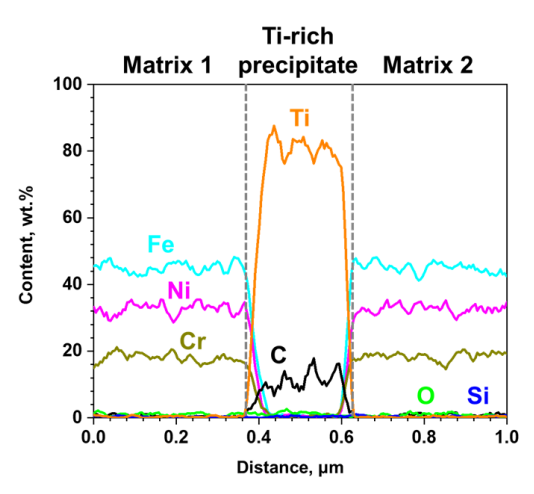

(c)

Figure 5. (a) SEM micrograph of PBHT-ed Alloy 800HT, and TEM analyses results at the bond-line; (b) STEM micrograph and (c) EDS line scanning.

\subsection{Tensile Properties and Microstructures after High Temperature $\mathrm{S}-\mathrm{CO}_{2}$ Exposure}

Based on the results of the tensile tests, one diffusion bonding condition was selected for each alloy for a subsequent corrosion test in $\mathrm{S}-\mathrm{CO}_{2}$ at $600{ }^{\circ} \mathrm{C}(20 \mathrm{MPa})$ for $1000 \mathrm{~h}$. For SS 316H, mini-sized tensile specimens were machined from the block of diffusion bonded at $1050{ }^{\circ} \mathrm{C} 8 \mathrm{MPa}$ and subjected to $\mathrm{S}-\mathrm{CO}_{2}$ exposure. For $800 \mathrm{HT}$, specimens that were fabricated from PBHT-ed blocks after diffusion bonding at $1150{ }^{\circ} \mathrm{C} 10 \mathrm{MPa}$ were selected. Room temperature tensile test results are shown in Figure 6. After $\mathrm{S}-\mathrm{CO}_{2}$ exposure, diffusion bonded SS $316 \mathrm{H}$ showed similar yield strength (YS) and UTS, while elongation was decreased (Figure 6a). However, it should be noted that only one of the two tensile specimens exposed to $\mathrm{S}-\mathrm{CO}_{2}$ failed at the bond-line, while the other failed at the base metal region and showed only slightly decreased elongation compared to the as-bonded condition. For PBHT-ed 800HT, there was an increase of YS and UTS after $\mathrm{S}-\mathrm{CO}_{2}$ tests. On the other hand, although the elongation of the diffusion bonded $800 \mathrm{HT}$ was recovered by PBHT, subsequent exposure to $\mathrm{S}-\mathrm{CO}_{2}$ resulted in a loss of elongation and brittle failure at the bond-line which was similar to the as-bonded condition (Figure 6b). Meanwhile, it should be mentioned that the tensile results of two samples per condition are not sufficient to draw reliable conclusions. Nonetheless, these results are useful as first indications of the integrity of diffusion bonded joints.

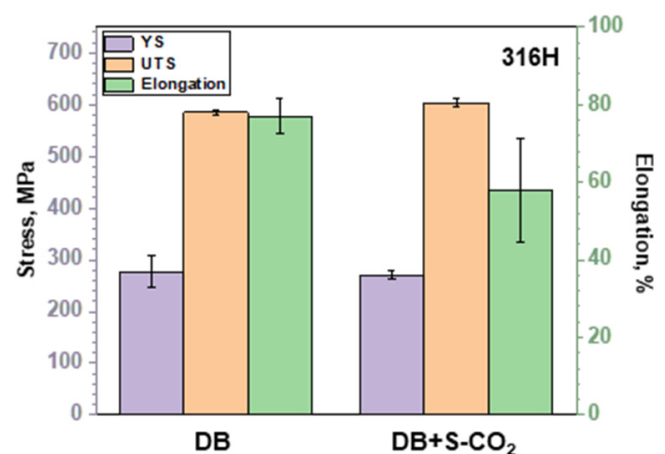

(a)

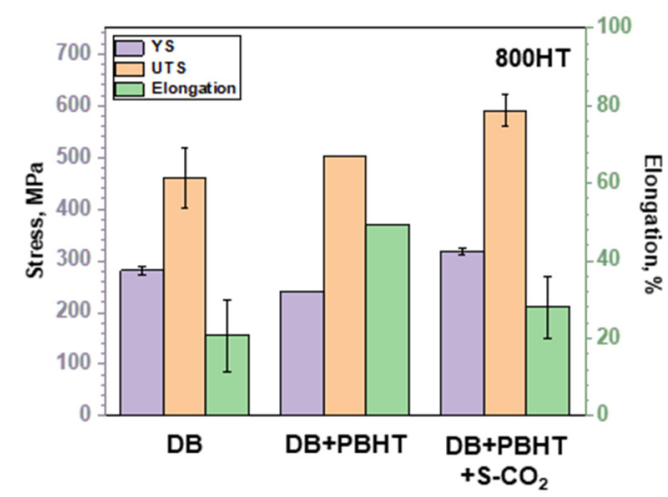

(b)

Figure 6. Room temperature tensile test results of (a) diffusion bonded SS $316 \mathrm{H}$ and (b) PBHT-ed Alloy $800 \mathrm{HT}$ after $\mathrm{S}-\mathrm{CO}_{2}$ exposure at $600{ }^{\circ} \mathrm{C}(20 \mathrm{MPa})$ for $1000 \mathrm{~h}$. 
A cross-sectional SEM analysis was conducted for surface oxides at the bond-line region for both alloys after the corrosion test in $\mathrm{S}-\mathrm{CO}_{2}$ at $600{ }^{\circ} \mathrm{C}(20 \mathrm{MPa})$ for $1000 \mathrm{~h}$. From SEM micrograph and EDS line scanning for diffusion bonded $316 \mathrm{H}$ (Figure $7 \mathrm{a}, \mathrm{c}$ ), the oxides were composed of an inner Fe/Cr-rich spinel layer, and a thicker outer Fe-rich oxide. The oxides formed above the bond-line did not seem to be different from those formed on the matrix away from the bond-line. Meanwhile, enrichment of $\mathrm{Cr}$ and $\mathrm{C}$ at the grain boundaries was observed. For Alloy $800 \mathrm{HT}$, a continuous Cr-rich oxide layer was formed both above the bond-line and in the matrix (Figure $7 \mathrm{~b}, \mathrm{~d}$ ). These observations are consistent with previous reports on oxidation of $316 \mathrm{H}$ and $800 \mathrm{HT}$ in high temperature $\mathrm{S}-\mathrm{CO}_{2}$ environments $[8,11]$.

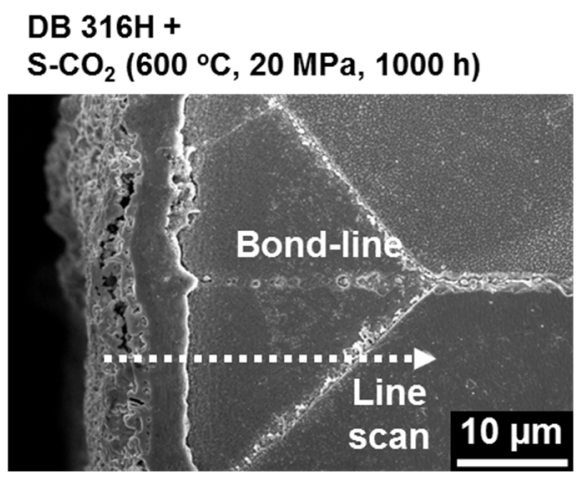

(a)

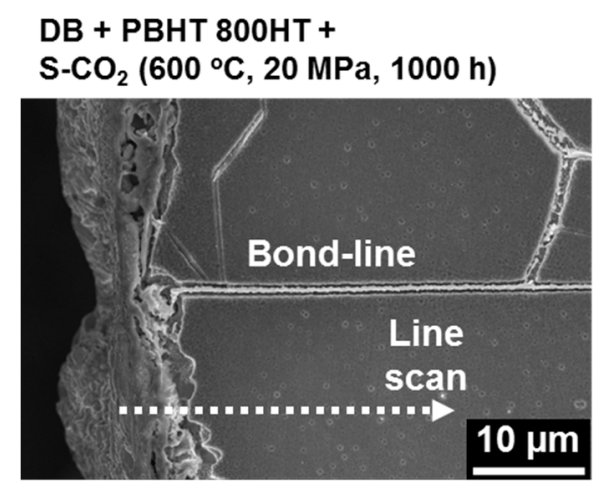

(b)

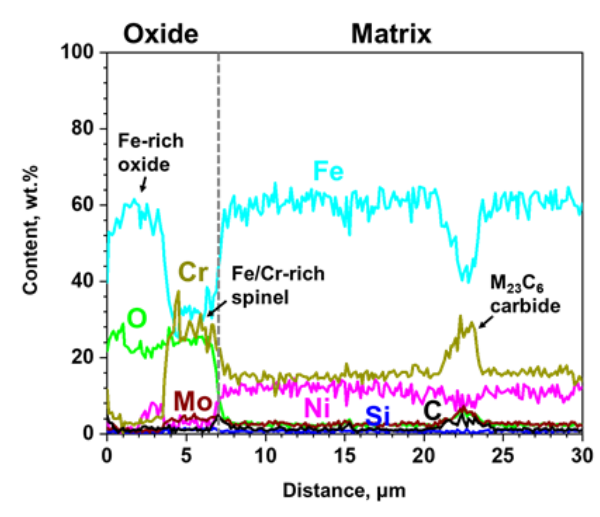

(c)

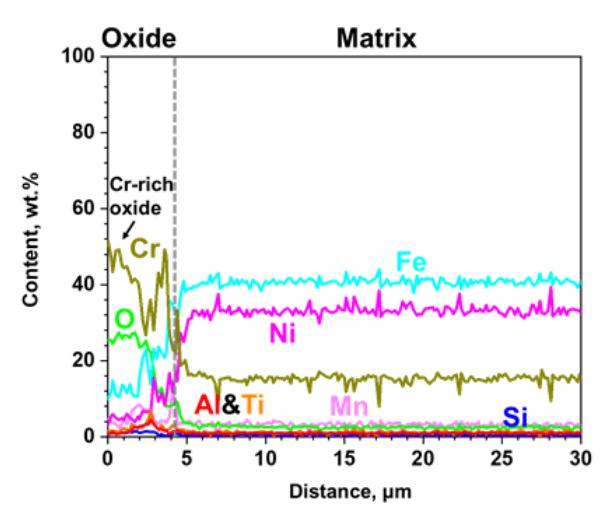

(d)

Figure 7. Cross-sectional SEM micrographs of (a) diffusion bonded SS $316 \mathrm{H}$ and (b) PBHT-ed Alloy $800 \mathrm{HT}$, and EDS line scanning of (c) diffusion bonded SS 316H and (d) PBHT-ed Alloy 800HT showing oxides at the bond-line region after $\mathrm{S}-\mathrm{CO}_{2}$ exposure at $600{ }^{\circ} \mathrm{C}(20 \mathrm{MPa})$ for $1000 \mathrm{~h}$.

Figure 8 shows the bond-line microstructures of diffusion bonded SS $316 \mathrm{H}$ at the inner region away from the surface after exposure to $\mathrm{S}-\mathrm{CO}_{2}$. The bond-line can still be recognized by the existence of precipitates. It is shown in the SEM micrographs (Figure $8 \mathrm{a}, \mathrm{b}$ ) that the precipitates are similar in morphology to those found previously in as-bonded condition (Figure 2a). The EDS line scanning result (Figure 8c) shows that the precipitate is rich in $\mathrm{Cr}, \mathrm{Mo}$, and $\mathrm{C}$, indicating that it is $\mathrm{M}_{23} \mathrm{C}_{6}$ carbide. The carbides are about $300 \mathrm{~nm}$ in size, which is similar to the as-bonded SS $316 \mathrm{H}$ (not shown), indicating that they did not grow during $\mathrm{S}-\mathrm{CO}_{2}$ exposure. For Alloy $800 \mathrm{HT}$, the bond-line remained planar after $\mathrm{S}-\mathrm{CO}_{2}$ exposure (Figure 9a,b), similar to the microstructure of the PBHT-ed condition (Figure 5a). The results of the TEM/EDS analyses at the bond-line region for the $\mathrm{S}-\mathrm{CO}_{2}$ exposed specimen are shown in Figure 9c,d. Ti-rich carbides remained at the bond-line, and their sizes were similar to those in PBHT-ed specimen. However, Cr-rich particles were formed at the bond-line between the Ti-rich 
carbides. Based on EELS mapping results (Figure 9e), it is thought that those newly-formed particles are $\mathrm{Cr}$-rich carbides.

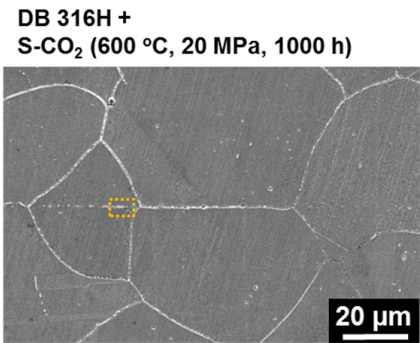

(a)

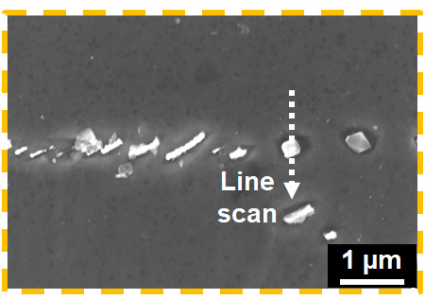

(b)

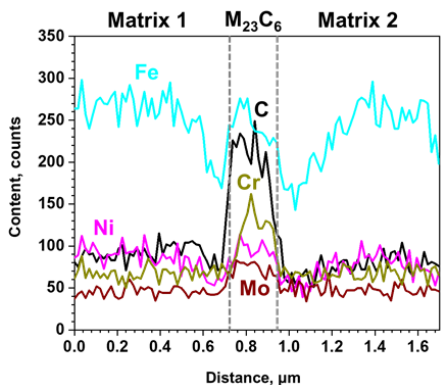

(c)

Figure 8. SEM analyses results of diffusion bonded $\mathrm{SS} 316 \mathrm{H}$ at the bond-line after $\mathrm{S}-\mathrm{CO}_{2}$ exposure at $600{ }^{\circ} \mathrm{C}(20 \mathrm{MPa})$ for $1000 \mathrm{~h}$; (a) Low magnification, (b) high magnification of the box in (a), and (c) EDS line scanning.

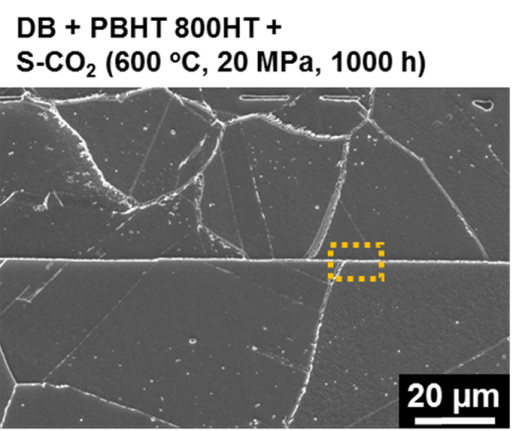

(a)

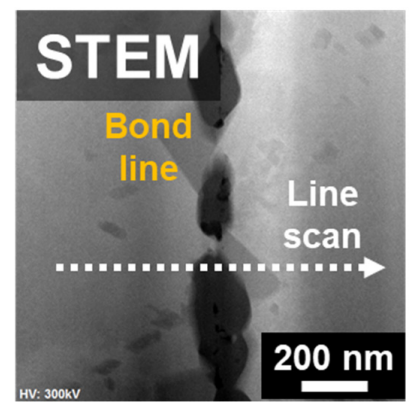

(c)

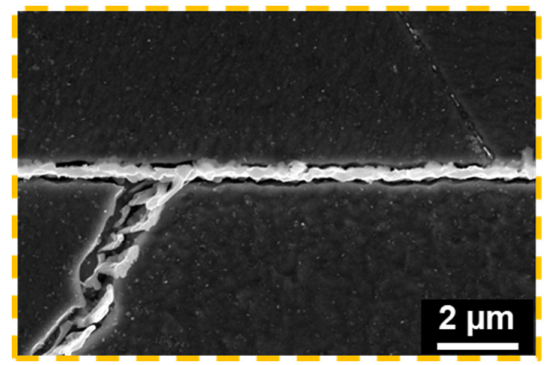

(b)

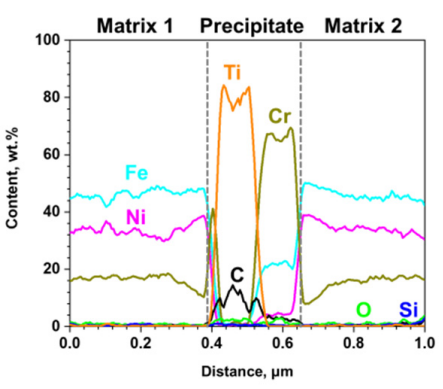

(d)
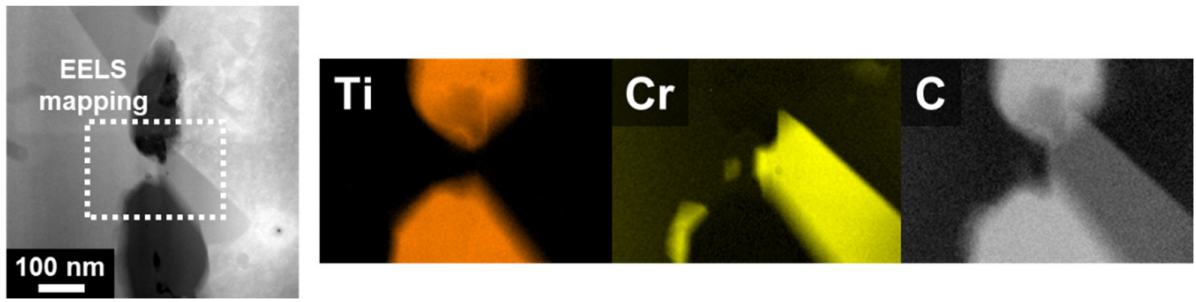

(e)

Figure 9. SEM analyses results of PBHT-ed Alloy $800 \mathrm{HT}$ at the bond-line after $\mathrm{S}-\mathrm{CO}_{2}$ exposure at $600{ }^{\circ} \mathrm{C}$ $(20 \mathrm{MPa})$ for $1000 \mathrm{~h}$; (a) Low magnification, (b) high magnification of the box in (a), and TEM analysis results; (c) STEM micrograph, (d) EDS line scanning and (e) EELS mapping image of precipitate. 


\section{Discussion}

\subsection{Microstructure at Diffusion Bonded Joints of Austenitic Fe-Base Alloys}

In this study, $\mathrm{Cr}$-rich carbides were formed as discontinuous islands at the bond-line after diffusion bonding of SS $316 \mathrm{H}$ (Figure 2). It is known that $\mathrm{M}_{23} \mathrm{C}_{6}$ carbide forms in 316-type stainless steels at temperatures of $400-900{ }^{\circ} \mathrm{C}$, even at short exposure times, e.g., $0.5 \mathrm{~h}$ at $750{ }^{\circ} \mathrm{C}$ [28,29]. Thus, the carbides formed at the bond interface during the initial temperature ramp up for diffusion bonding. These carbides would not have fully dissolved into the matrix during diffusion bonding, as the bonding temperature $\left(1050{ }^{\circ} \mathrm{C}\right)$ was at the lower bound of the solution annealing temperature and the diffusion bonding time $(1 \mathrm{~h})$ was rather short. Nonetheless, the existence of the $\mathrm{Cr}$-rich carbides at the bond-line did not hinder grain boundary migration across the bond interface, and the tensile properties of the diffusion bonded specimen were not significantly affected (Figure 1). Meanwhile, PBHT at $1100{ }^{\circ} \mathrm{C}$ for $5 \mathrm{~h}$ fully dissolved these carbides and made the bond-line indistinguishable from the matrix.

For Alloy $800 \mathrm{HT}$, precipitates were also found at the bond-line after diffusion bonding; these were found to be Ti-rich carbides. The carbides were continuously formed along the bond-line, and inhibited grain boundary migration, resulting in a planar bond interface (Figure 2c). Such Ti-rich precipitates were also observed for diffusion bonded Alloy 600 in a previous study [30]. In that study, partial grain boundary migration across the bond-line was achieved, but with substantial compressive pressure causing deformation of the blocks. Meanwhile the Ti-rich precipitates still remained. It is known that Ti-rich carbides and nitrides form in the matrix of Alloy 800HT and Ni-base alloys containing Ti. These precipitates are highly stable and unaffected by heat-treatments. Thus, the Ti-rich carbides that formed at the bond-line could not be removed by the PBHT (Figures 3 and 5). Despite the existence of Ti-rich carbides at the bond-line, PBHT of diffusion bonded Alloy 800HT resulted in improvement of tensile elongation. Microstructural analyses revealed that the Ti-rich carbides grew in size after PBHT and became discontinuous, such that some metallic regions were formed at the bond-line (Figure 5b). These metallic regions should have improved tensile elongation. Also, the PBHT removed the small recrystallized grains adjacent to the bond-line which should have increased the stress concentration at that region during tensile test. Thus, the removal of small recrystallized grains during PBHT may have also contributed to the increased elongations of diffusion bonded Alloy 800HT (Figure 4b).

\subsection{Effect of $\mathrm{S}-\mathrm{CO}_{2}$ Exposure on Diffusion Bonded Joints of SS $316 \mathrm{H}$}

As shown in Figure 6, elongation was reduced after $\mathrm{S}-\mathrm{CO}_{2}$ exposure for diffusion bonded SS $316 \mathrm{H}$. The microstructures of the diffusion bonded joint of $\mathrm{SS} 316 \mathrm{H}$ before and after $\mathrm{S}-\mathrm{CO}_{2}$ exposure are compared in Figure 10a. It seems that there was a slight increase in carbides precipitates on the bond-line and in the grain boundaries after $\mathrm{S}-\mathrm{CO}_{2}$ exposure, which could be the reason for the observed reduction of elongation. Figure $10 \mathrm{~b}$ shows SEM micrographs of tensile-tested specimens of diffusion bonded SS $316 \mathrm{H}$ before and after $\mathrm{S}-\mathrm{CO}_{2}$ exposure. The diffusion bonded specimen shows a ductile fracture away from the bond-line. For the $\mathrm{S}-\mathrm{CO}_{2}$ exposed specimens, one failed away from the bond-line in similar manner, but the other failed along the bond-line, showing a flat failure surface. However, it should be noted that the specimen underwent significant uniaxial deformation before final fracture at the bond-line. The grain boundary carbides were more pronounced for the S-CO exposed specimen. 
$\mathrm{DB} 316 \mathrm{H}\left(1050^{\circ} \mathrm{C}, 8 \mathrm{MPa}, 1 \mathrm{~h}\right)$

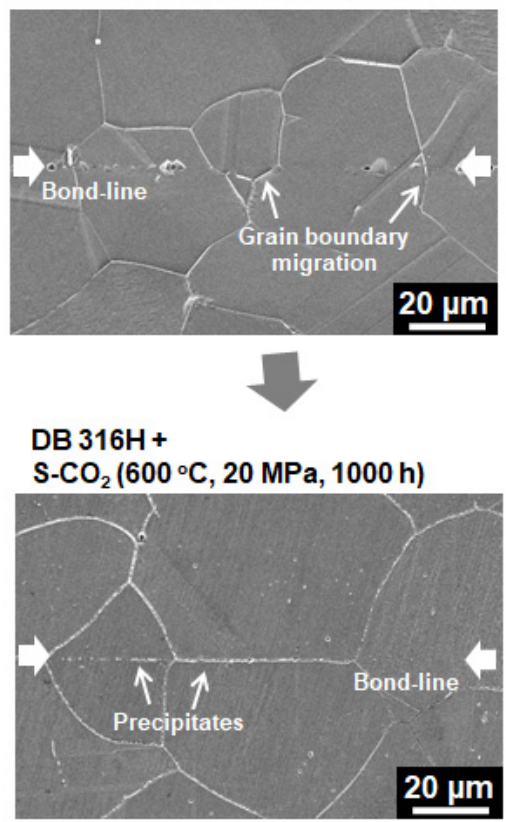

(a)

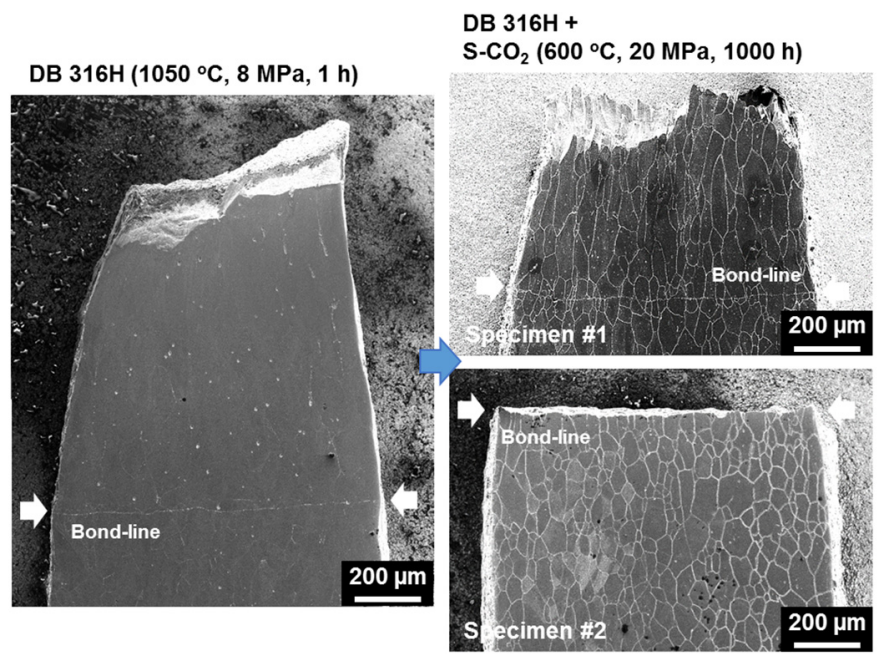

(b)

Figure 10. SEM micrographs of (a) diffusion bonded joint and (b) tensile-tested specimens of diffusion bonded SS $316 \mathrm{H}$ before and after $\mathrm{S}-\mathrm{CO}_{2}$ exposure at $600{ }^{\circ} \mathrm{C}(20 \mathrm{MPa})$ for $1000 \mathrm{~h}$.

\subsection{Effect of $\mathrm{S}-\mathrm{CO}_{2}$ Exposure on Diffusion Bonded Joints of Alloy 800HT}

As shown in Figure 6, elongation was significantly reduced after $\mathrm{S}-\mathrm{CO}_{2}$ exposure for diffusion bonded Alloy 800HT. Ageing of diffusion bonded blocks was conducted for Alloy 800HT in Ar at $600{ }^{\circ} \mathrm{C}$ for $1000 \mathrm{~h}$ to check the effects. Figure 11a shows SEM micrographs taken in the middle of diffusion bonded $800 \mathrm{HT}$ after various treatments, in which carbide size and morphology at the bond-line can be compared. It is clear that both bond-line and grain boundaries are covered with carbides and the degree of carbide coverage is greater for the aged and $\mathrm{S}-\mathrm{CO}_{2}$ exposed specimen. In previous sections, the carbides at the bond-line were identified as elongated and continuous along the bond-line (as-bonded, Figure 2), globular and discontinuous (after PBHT, Figure 5), and continuous with additional $\mathrm{Cr}$-rich carbides along with Ti-rich carbides (after $\mathrm{S}-\mathrm{CO}_{2}$ exposure, Figure 9). Therefore, during high temperature exposure (ageing and $\mathrm{S}-\mathrm{CO}_{2}$ exposure), $\mathrm{Cr}$-rich carbides were extensively formed on the bond-line and grain boundaries of diffusion bonded Alloy 800HT. In addition, Figure 11b shows the bond-line carbides near the surface oxide layer for the $\mathrm{S}-\mathrm{CO}_{2}$ exposed specimen, similar to those at the middle of the specimen (bottom-right image of Figure 11a). From this observation, it could be said that $\mathrm{C}$ came from the matrix, and carbide growth at the bond-line occurred because of high temperature $\left(600{ }^{\circ} \mathrm{C}\right)$ ageing rather than due to the $\mathrm{S}-\mathrm{CO}_{2}$ environment. These results are similar to a previous report by Chen et al. [31] in which diffusion bonded Alloy 690 was exposed to S-CO environments and $\mathrm{Cr}$-rich carbides were found in the grain boundaries and bond-line of diffusion bonded Alloy 690.

Figure 11c shows SEM micrographs of tensile-tested specimens of diffusion bonded Alloy 800HT before and after $\mathrm{S}-\mathrm{CO}_{2}$ exposure. The diffusion bonded specimen shows brittle fracture at the bond-line with little elongation (Figure 4). The application of PBHT changed the failure location away from the bond-line and resulted in significant recovery in elongation (Figure 6); the change of morphology of Ti-rich carbides along the bond-line may have contributed to this. However, additional exposure to $\mathrm{S}-\mathrm{CO}_{2}$ resulted in failure at the bond-line and elongation was reduced again. The overall changes in fracture behavior are consistent with the carbides coverage on bond-line and grain boundaries shown in Figure 11a. A similar relationship between carbide precipitates and fracture behavior was reported for diffusion bonded Alloy 690 by Chen et al. [31]. 


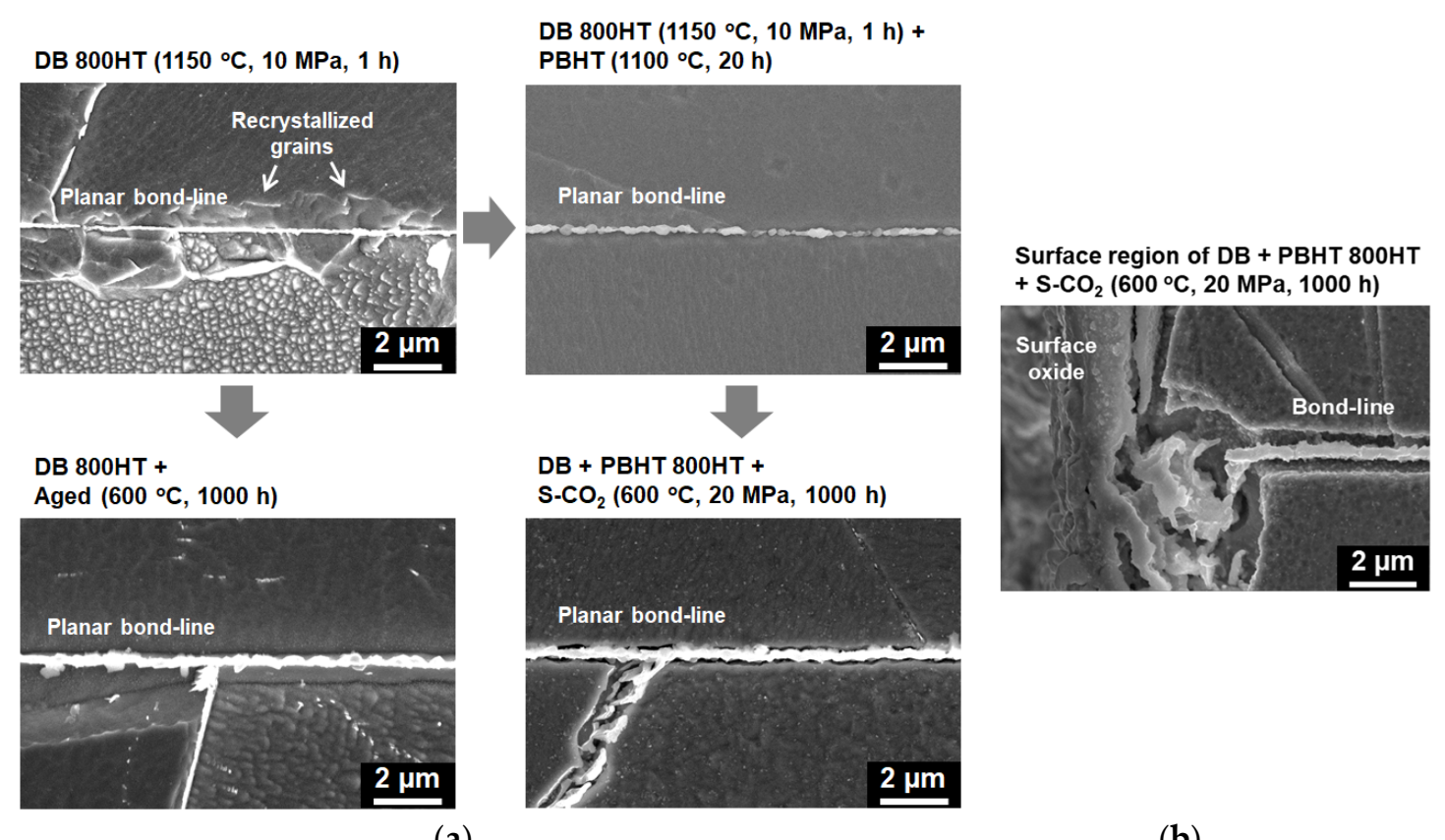

(a)

(b)

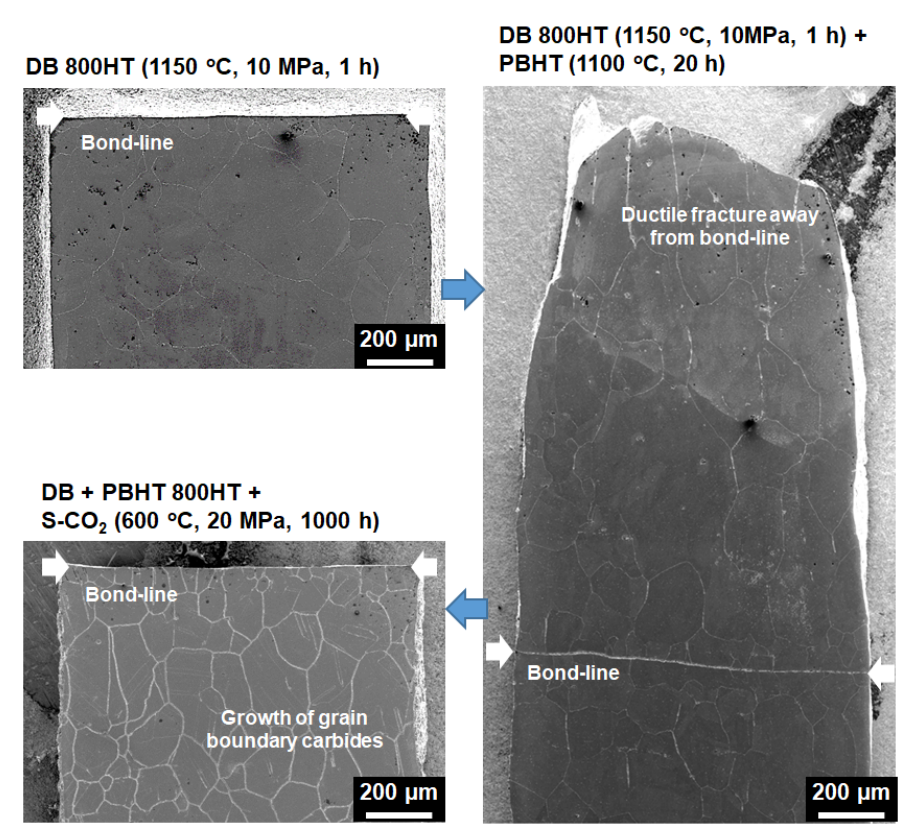

(c)

Figure 11. SEM micrographs of (a) at the middle and (b) surface of diffusion bonded joints, and (c) tensile-tested specimens of diffusion bonded Alloy $800 \mathrm{HT}$ before and after $\mathrm{S}-\mathrm{CO}_{2}$ exposure at $600{ }^{\circ} \mathrm{C}$ (20 MPa) for $1000 \mathrm{~h}$.

The above observations suggest that the $\mathrm{S}-\mathrm{CO}_{2}$ environment did not have a significant effect on bond-line microstructure and mechanical properties of diffusion bonded alloys. Rather, the effect of prolonged exposure to high temperature was of greater effect. In addition, it is quite apparent that the initial bond-line microstructure after diffusion bonding is of the greatest importance. A planar bond-line with precipitates, such as the one observed in the diffusion bonded Alloy $800 \mathrm{HT}$, would be susceptible to premature fracture during service. Some studies have investigated the effectiveness of a Ni interlayer in order to incite grain boundary migration for Ni-base alloys during diffusion bonding, and reported improvements in the mechanical properties of the diffusion bonded joints $[17,23,32]$. Therefore, further 
studies on the effect of a Ni interlayer on microstructure and mechanical properties of diffusion bonded Fe-based austenitic alloys are needed to achieve better performance at high temperatures.

\section{Conclusions}

Diffusion bonding of austenitic Fe-base alloys SS $316 \mathrm{H}$ and Alloy $800 \mathrm{HT}$ was conducted under various temperatures. The microstructure and tensile properties of the diffusion bonded specimens were evaluated before and after S- $\mathrm{CO}_{2}$ exposure at $600{ }^{\circ} \mathrm{C}(20 \mathrm{MPa})$ for $1000 \mathrm{~h}$. Based on the results of tensile tests and microstructural analyses, the following conclusions were drawn.

1. For diffusion bonded SS 316H, grain boundary migration occurred across the bond interface, while some discontinuous $\mathrm{Cr}$-rich carbides existed along the bond-line. Meanwhile, continuous Ti-rich carbides along the bond-line and small, recrystallized grains adjacent to the bond-line were observed for diffusion bonded 800HT.

2. For both diffusion bonded SS $316 \mathrm{H}$ and Alloy $800 \mathrm{HT}$, tensile elongation was lower than as-received materials. The reduction of ductility was much greater for diffusion bonded Alloy $800 \mathrm{HT}$ with brittle failure at the bond-line, regardless of the diffusion bonding temperature

3. Post-bond heat treatments resulted in improved tensile properties for both diffusion bonded alloys. PBHT-ed SS 316H showed decreased UTS and increased elongation that is typically related to grain growth. In addition, $\mathrm{Cr}$-rich carbides at the bond-line were dissolved into the matrix, so that the bond-line could not be identified after PBHT of diffusion bonded SS 316H. Elongation at the fracture of diffusion bonded Alloy $800 \mathrm{HT}$ was recovered by PBHT to similar values as those of as-received material. Microstructural analyses revealed the change of bond-line Ti-rich carbides into discontinuous islands and the absence of recrystallized grains after PBHT.

4. Diffusion bonded SS 316H and PBHT-applied Alloy 800HT exhibited reduced elongation at fracture after $\mathrm{S}-\mathrm{CO}_{2}$ exposure. Microstructure observations revealed the formation of $\mathrm{Cr}$-rich carbides at the bond-line and grain boundaries, especially for aged and $\mathrm{S}-\mathrm{CO}_{2}$ exposed diffusion bonded Alloy $800 \mathrm{HT}$. The reduction of elongation was caused by the formation of Cr-rich carbide during high temperature exposure; the $\mathrm{S}-\mathrm{CO}_{2}$ environment did not have a significant effect on the bond-line microstructure and mechanical properties of the diffusion bonded alloys.

Author Contributions: Formal analysis, S.H.K. and J.-H.C.; investigation, S.H.K. and I.S.; data curation, S.H.K.; writing—original draft preparation, S.H.K.; writing—review and editing, C.J.; supervision, C.J.; project administration, I.S.; All authors have read and agreed to the published version of the manuscript.

Funding: This research was funded by the National Research Foundation of the Ministry of Science and ICT (NRF/MSIT) of the Rep. of Korea, grant number 2020M2A8A4023937. The APC was funded by the National Research Foundation of the Ministry of Science and ICT (NRF/MSIT) of the Rep. of Korea, grant number 2020M2A8A4023937.

Acknowledgments: Financial support for two of the authors is provided by the BK-Plus Program of the NRF/MSIT of the Rep. of Korea.

Conflicts of Interest: The authors declare no conflict of interest.

\section{References}

1. Dostal, V.; Hejzlar, P.; Driscoll, M.J. The supercritical carbon dioxide power cycle: Comparison to other advanced power cycles. Nucl. Technol. 2006, 154, 283-301. [CrossRef]

2. Ahn, Y.; Bae, S.J.; Kim, M.; Cho, S.K.; Baik, S.; Lee, J.I.; Cha, J.E. Review of supercritical $\mathrm{CO}_{2}$ power cycle technology and current status of research and development. Nucl. Eng. Tech. 2015, 47, 647-661. [CrossRef]

3. Dostal, V.; Hejzlar, P.; Driscoll, M.J. High-performance supercritical carbon dioxide cycle for next-generation nuclear reactors. Nucl. Technol. 2006, 154, 265-282. [CrossRef]

4. Mecheri, M.; Moullec, Y.L. Supercritical $\mathrm{CO}_{2}$ Brayton cycles for coal-fired power plants. Energy 2016, 103, 758-771. [CrossRef]

5. Bocher, F.; Allison, T.; Shin, B.G.; Lee, S. Materials evaluation and corrosion test needs for a direct-fired SCO2 oxy-combustion plant. In Proceedings of the 6th International Supercritical $\mathrm{CO}_{2}$ Power Cycles Symposium, Pittsburgh, PA, USA, 27-29 March 2018. 
6. Iverson, B.D.; Conboy, T.M.; Pasch, J.J.; Kruizenga, A.M. Supercritical $\mathrm{CO}_{2}$ Brayton cycles for solar-thermal energy. Appl. Energy 2013, 111, 957-970. [CrossRef]

7. Firouzdor, V.; Sridharan, K.; Cao, G.; Allen, T.R. Corrosion of a stainless steel and nickel-based alloys in high temperature supercritical carbon dioxide environment. Corros. Sci. 2013, 69, 281-291. [CrossRef]

8. Lee, H.J.; Kim, H.; Kim, S.H.; Jang, C. Corrosion and carburization behavior of chromia-forming heat resistant alloys in high-temperature supercritical-carbon dioxide environment. Corros. Sci. 2015, 99, 227-239. [CrossRef]

9. Lee, H.J.; Subramanian, G.O.; Kim, S.H.; Jang, C. Effect of pressure on the corrosion and carburization behavior of chromia-forming heat-resistant alloys in high-temperature carbon dioxide environments. Corros. Sci. 2016, 111, 649-658. [CrossRef]

10. Pint, B.A.; Unocic, K.A.; Brese, R.G.; Keiser, J.R. Characterization of chromia scales formed in supercritical carbon dioxide. Mater. High Temp. 2018, 35, 39-49. [CrossRef]

11. Cao, G.; Firouzdor, V.; Sridharan, K.; Anderson, M.; Allen, T.R. Corrosion of austenitic alloys in high temperature supercritical carbon dioxide. Corros. Sci. 2012, 60, 246-255. [CrossRef]

12. Rouillard, F.; Furukawa, T. Corrosion of 9-12Cr ferritic-martensitic steels in high-temperature $\mathrm{CO}_{2}$. Corros. Sci. 2016, 105, 120-132. [CrossRef]

13. Gui, Y.; Liang, Z.; Zhao, Q. Corrosion and carburization behavior of heat-resistant steels in a high-temperature supercritical carbon dioxide environment. Oxid. Met. 2019, 92, 123-136. [CrossRef]

14. Chen, H.; Kim, S.H.; Kim, C.; Chen, J.; Jang, C. Corrosion behaviors of four stainless steels with similar chromium content in supercritical carbon dioxide environment at $650{ }^{\circ} \mathrm{C}$. Corros. Sci. 2019, 156, 16-31. [CrossRef]

15. Chu, W.; Li, X.; Ma, T.; Chen, Y.; Wang, Q. Experimental investigation on $\mathrm{SCO}_{2}$-water heat transfer characteristics in a printed circuit heat exchanger with straight channels. Int. J. Heat Mass Tran. 2017, 113, 184-194. [CrossRef]

16. Saranam, V.R.; Paul, B.K. Feasibility of using diffusion bonding for producing hybrid printed circuit heat exchangers for nuclear energy applications. Procedia Manuf. 2018, 26, 560-569. [CrossRef]

17. Mylavarapu, S.K.; Sun, X.; Christensen, R.N.; Unocic, R.R.; Glosup, R.E.; Patterson, M.W. Fabrication and design aspects of high-temperature compact diffusion bonded heat exchangers. Nucl. Eng. Des. 2012, 249, 49-56. [CrossRef]

18. Gietzelt, T.; Toth, V.; Huell, A. Joining Technologies; IntechOpen: London, UK, 2016; Chapter 9; pp. $195-216$. [CrossRef]

19. Samouhos, M.; Peppas, A.; Angelopoulos, P.; Taxiarchou, M.; Tsakiridis, P. Optimization of copper thermocompression diffusion bonding under vacuum: Microstructural and mechanical characteristics. Metals 2019, 9, 44. [CrossRef]

20. Gietzelt, T.; Toth, V.; Huell, A. Challenges of diffusion bonding of different classes of stainless steels. Adv. Eng. Mater. 2018, 20, 1-10. [CrossRef]

21. Zhang, G.; Chandel, R.S.; Seow, H.P. Solid state diffusion bonding of Inconel 718. Sci. Technol. Weld. Joi. 2001, 6, 235-239. [CrossRef]

22. Ravisankar, B.; Krishnamoorthi, J.; Ramakrishnan, S.S.; Angelo, P.C. Diffusion bonding of SU 263. J. Mater. Process. Tech. 2009, 209, 2135-2144. [CrossRef]

23. Kapoor, M.; Dogan, O.; Rozman, K.; Hawk, J.; Wilson, A.; L'Estrange, T.; Narayanan, V. Diffusion bonding of $\mathrm{H} 230 \mathrm{Ni}$-superalloy for application in microchannel heat exchangers. In Proceedings of the 5th International Supercritical $\mathrm{CO}_{2}$ Power Cycles Symposium, San Antonio, TX, USA, 28-31 March 2016.

24. Sah, I.; Kim, D.; Lee, H.J.; Jang, C. The recovery of tensile ductility in diffusion-bonded Ni-base alloys by post-bond heat treatments. Mater. Des. 2013, 47, 581-589. [CrossRef]

25. Lee, H.J.; Kim, S.H.; Jang, C. Characterization of Alloy 600 joints exposed to a high-temperature supercritical-carbon dioxide environment. Mater. Charact. 2018, 138, 245-254. [CrossRef]

26. Dogan, O.; Carney, C.; Oleksak, R.P.; Disenhof, C.R.; Holcomb, G.R. High-temperature corrosion of diffusion bonded Ni-based superalloys in $\mathrm{CO}_{2}$. In Proceedings of the 5th International Supercritical $\mathrm{CO}_{2}$ Power Cycles Symposium, San Antonio, TX, USA, 28-31 March 2016.

27. Sridharan, K. Corrosion of structural materials for advanced supercritical carbon-dioxide brayton cycle, NEUP final report (13-4900). 2017. [CrossRef]

28. Weiss, B.; Stickler, R. Phase instabilities during high temperature exposure of 316 austenitic stainless steel. Metall. Mater. Trans. B 1972, 3, 851-866. [CrossRef]

29. Sourmail, T. Precipitation in creep resistant austenitic stainless steels. Mater. Sci. Technol. 2001, 17, 1-14. [CrossRef] 
30. Kim, S.H.; Kim, C.; Jang, C. Diffusion bonding of a cold-worked Ni-base superalloy. In Proceedings of the ASME 2018 Symposium on Elevated Temperature Application of Materials for Fossil, Nuclear, and Petrochemical Industries, Washington, DC, USA, 3-5 April 2018. [CrossRef]

31. Chen, H.; Kim, S.H.; Jang, C. Effect of high-temperature supercritical carbon dioxide exposure on the microstructure and tensile properties of diffusion-bonded Alloy 690. J. Mater. Sci. 2020, 55, 3652-3667. [CrossRef]

32. Duvall, D.S.; Owczarski, W.A.; Paulonis, D.F.; King, W.H. Methods for diffusion welding the superalloy Udimet 700. Weld. Res. Suppl. 1972, 41s-49s. Available online: https://app.aws.org/wj/supplement/WJ_1972_ 02_s41.pdf (accessed on 15 March 2020).

(C) 2020 by the authors. Licensee MDPI, Basel, Switzerland. This article is an open access article distributed under the terms and conditions of the Creative Commons Attribution (CC BY) license (http://creativecommons.org/licenses/by/4.0/). 